\title{
Ambiguity in Changing Stances in Sarah Macdonald's Holy Cow! An Indian Adventure
}

\section{Nimisha F.}

Assistant Professor, Department of English, ST. Joseph's College for Women, Alappuzha, Kerala, India

\begin{abstract}
Putting the world on paper' as travel writing can be simply defined, has been identified as a mode of colonialist discourse that reinforces European norms. As a genre, it provides insight into the fraught encounters and exchanges taking place between cultures, and the lives being led, and the subjectivities being formed, in a globalising world. With the spread of 'postcolonial studies', the academic interest in travel writing has increased dramatically. Postcolonial scholars sought to understand the processes that first created these inequalities that currently exist between the different regions of the worldand concerned themselves more with questions relating to how cultures regard and depict each other, and how they interact.
\end{abstract}

Keywords-Postcolonial Travel, East/West, 'Other', Colonial Mimicry, Spiritual Confirmation.

Postcolonial travel writers seek to challenge Western assumptions and stereotypes and thereby deconstructing the received notions about the colonized nations. While studying these travel narratives, one of the first issues that comes to mind is that of narrative authority. As postcolonial travellers construct themselves in the text, what is it that they are looking for in their travels? Does the traveller move beyond the traditional binaries of superior/inferior culture so characteristic of colonial travel writing? Are they looking for 'otherness' or for conformation? Do they tend to take a privileged space, or is it the 'observed' that occupy a desired privileged space? And what role does colonial mimicry play in this process? This paper intends to probe the ambiguity in presenting India as a nation in Sarah Macdonald's Holy Cow! An Indian Adventure, a light hearted memoir wherein she describes her life experience which she had gone through by spending two years in Delhi.

While working with ABC, Macdonald made a journey to India which she describes as a 'rollercoaster ride' in search of the meaning of life and death. Travelling usually means leaving familiar surroundings and going to places and experiencing the difference which may pose a threat to one's identity, ie, to question one's concept of 'Self' and 'Other'. When Macdonald first came to India in 1988, she was welcomed my beggars and potters with the high pitched wheezy whining calls 'Madam, Pleazzzzzzze'. She is sarcastic of the plastic airport chairs and the "violent double-ended projectile vomits and diarrhea explosions off the bathroom walls" (9). The stink of mothballs, the breath reeks of pan, the green, yellow, red stains of teeth of beggars are all what she sees first in India and she firmly says good bye to India and promises never to come back. But destiny makes her come back to India after long eleven years and she finds everything unchanged.

Macdonald finds that the early mornings are not attractive to travel in India with bum salute of slumdwellers squatting beside the tracks doing their morning 'ablutions'. She scrons the remarkable ability of Indians to look without seeing.

"They do not notice the child grabbing their shawl, the beggar pulling at their pants, the filth, the misery, the public nose picking, pissing or pooing, and they seem deaf to the call of the country a violent guttural growling retch: croooooooooooooooooooooooooooaaaaaa aaaaakk, punctuated by a giant spit of the phlegm: pppppppppppppppppppppppppppttttttttttt ttttttttttttttttttaaaaaaaaaaaaaaaaaaaab!. It is a sound that punctuates morning, noon and night. (21)

Macdonald mocks at the way Indians treat and judge people according to their skin colour. She feels that in India she is famous for being white. The way men gap 
and giggle hysterically at her arse when she goes out wearing a hideously baggy pants give her a shellshock. Her detest and amusement increase on her way to Rishikesh where sadhus and beggars worship she and her boyfriend Jonathan as walking dollar signs; and are constantly surrounded, followed, hassled and ordered to give money or to buy something. Macdonald is fed up of the staring looks from buses and truck-drivers. She is sick of the cocky display of penis. She finds the Indian overload of male attention as dehumanizing and debilitating making forgiveness, love and understanding of fellow humans almost impossible. MacDonald frequently presents Jonathan as an action hero, a figure of exemplary courage and man liness and for her all other Indian men are considered to be persons with the quality of 'moroseness'.

It is often assumed that the motives behind such pejorative or patronising portrayals of other cultures will be unconscious and over-determined, springing from a complex mixture of emotions, such as fear, envy, revulsion, incomprehension and sometimes even desire, when another culture stirs taboo fantasies that travellers wish to repress and disown. Very often, instances of pejorative 'othering' in travel writing serve an important justificatory function. They may legitimate the traveller's personal conduct towards the people he or she met crucially. The traveller's portrayal of another place or people is often in this way ideologically motivated, seeking at some level to justify and encourage a particular policy or course of action towards those others.

India for her is "Hotel California: you can check out anytime you like, but you can never leave"(9); and the Indians are 'ugly lepers' and 'skinny Adams family'. She classifies Indians as anglophiles who are obsessed with foreigners and have their fingers in their noses or other parts of their anatomy. She doesn't meet a single Indian who could speak English properly. According to her everybody's face resembles as that of some animals. In all the 'meditation camps' that she frequents, the Indians are the only ones who quit before everybody else or they are unable to grasp the 'true meaning'. While highlighting the crowd, stink in all the tourist spots, she talks of India as a "place unfit for human inhabitation, it's mad! Why are we here? What the hell have I done? I've left my job for this place! Why can't we be normal and live where we were born? Sydney is safe" (32). The orient in her generalizes everything about India when she says Indians are the only ones spreading the garbage whereas all the others are very careful about their cleanliness.
In the Location of Cultures, Homi K. Bhabhadefines the concept of colonial mimicry associated with postcolonial studies. Bhabha's concept of mimicry is a strategy of colonial power/knowledge which has a desired goal for the inhabitants of approval and changed outlooks in terms of inclusion and exclusion. While inclusion aims the acceptance of 'god natives' as the colonizers programmers and exclusion puts the goal of denouncing the majority 'bad natives'. Seeing a bus driver dragging a beggar from the road who was lying on the road struck by some vehicle, Sarah Macdonald says "India is the worst of humanity" (80). And the very next moment when she sees the local beggar Pooja, feelings of pity and compassion are aroused: "India is the best of humanity"(80).

The notion of sentimentality associated with women travel writers is felt when she comments on the lives of men and women in India. The oriental male was frequently deemed insufficiently 'manly' and displayed a luxuriousness and foppishness that made him appear as a grotesque parody of the 'gentler' fe male sex. The exoticised oriental female, often depicted nude or partially-clothed in hundreds of western works of art during the colonial period, is presented as an immodest, active creature of sexual pleasure who held the key to a myriad of mysterious erotic delights. Sarah is alarmed at the gender discrimination in India and comments on the greatest evil in India.

Most often, women travelers stood in ambiguous relation with colonial projects as they are doubly colonized by gender and race. The affinity they show generate greater openness towards other cultures, and a greater sympathy with the plight of indigenous populations. Sarah MacDonald becomes a mere occident with looking glass through which she considers Indian women as passive, moral and chaste. They are denied of choosing their own life partners. It is the family of the girl who decides the upcoming son-in-law. Her friend Padma's mother commits suicide for Padma brought dishonor to her family by falling in love. The author comments that for women with choices, death can deliver status and honour. Padma makes her realize that India is in love just with the idea of romance. People love to watch romance and such songs and scenes on the big screen but there is a gulf between real and reel. Sarah is alarmed as in India a women is not much without a husband. Once, a neighbor told her mother that her dad mustn't have cared for her much because he left her. Widows are considered as worthless and bad luck.

It would be also naïve to as sume that wo men travel writers today face no constraints, and that there are no 
gender expectations which they have to negotiate, either as they travel or as they write. The fear of violence, and especially of sexual violence, arguably remains a more pressing concern for female than male travel writers. The cultures that they visit, will sometime require different conduct and costume from women. Sarah Macdonald becomes conscious day by day that she makes sure that she is wearing a salwar with duppatta across her breasts to cover it.

Prior to her exploration of India's s morgasbord of spirituality, she found the Gods and semi-Gods amusing. She gives an entertaining description of the A mbas sador car she hires: "dashboard has a fluorescent Ganesh (the elephant god), an orange toy cow, a snow dome of Satya Sai Baba (the Afro-aired living god of Bangalore), and a blue plastic Shiva god bouncing on a spring, a brown, four armed Barbie in a sari stands on a lotus and she has an aura of tiny lights that flash when we brake"(23).

Macdonald becomes more interesting and informative as she moves from being a passively observing traveller making wisecracks to an active participant in India's spiritual marketplace. She samples large scale events like the MahaKumbhMela in Allahabad, the Our Lady of Velangani in Tamil Nadu, the Golden Temple in Amritsar, the Sai Baba Ashram near Bangalore, Mata Amritanadamayi's Ashram in Kerala, and the Tibetan Buddhist centre in Dharmasala. She also explores smaller, more marginal traditions including Vipassana Buddhist meditation, the Parsi of Malabar Hill, the now-fading Bene Israel Jewish community. Though she doesn't visit any major mosques in India, she shares her experience in Muslim-dominated Kashmir. Macdonald considers whether the religion she encounters is something she can connect with, and whether its something she would want in her life in an ongoing way. She dabbles in ten different religious traditions in the course of two years.

At times, during her journey, when she encounters different people and confronts different cultures and religions, she gets the spark of the flame that is fuming inside her. She feels that India is a spiritual homeland but that does not cure all spiritual illness. In India she had travelled a soul's journey: from hedonism to sickness, from silence to song, from violence to peace, and from learning to die to celebrating life. "Yet a s mall flame within me has been lit by what I've shared, a flame that warns me with a realization, India: a land that shares its sacred space, seems a spiritual home worth having" (199).
Sarah Macdonald's confirmation with India comes through her encounter with the different religions here. She attributes everything good happened her to Mata AmritanandaMayi (Amma) whom she met in Kerala. Macdonald is astonished to find a female human God in a man's world. As a result of female in fanticide, girl babies are aborted, undernourished and murdered, there are fifty two men for every forty-eight women. After meeting Amma, she decides not to judge people harshly and to treat India better. She realizes love as a compelling tool that has the power to gain respect from fellow Indians. Macdonald's observes that India is particularly suited to take from western culture what it wants from it without losing its conservative nature because it is already a very pluralistic society that allows religious tolerance. After the spiritual odyssey, she considers herself as a rejuvenated self embracing everything that is 'other' but one finds her intentionally or unintentionally projecting the superior/inferior, East/West dichotomy when she says: "I feel guilty for being in a position where I'm privileged enough to be a giver than a taker and I feel guilty for wanting more than I have and taking what I do have for granted. . . But most of all I feel confused ad confronted. Why was I born in my safe, secure, sunny Sydney sanctuary and not in Kesroli?"'(128).

Macdonald's reconciliation with India leaves one bewildered. It is the spiritual encounters that she had brought in the transformation of her 'self' that was pooling between 'self' and 'other'. She has shed the old mind, body and hair. She calls herself a newborn babe budding in India's spiritual supermarket. With the thought of regrowth in mind, Sarah hesitates not to re-embrace the life of a material girl living in a material world, but Sydney has teased her with luxury. While India may well have a soft spiritual centre, it's also got a hard head for cash, and the middle class is embracing the products and symbols of Western consumer culture. During her visit to the famous Velangani Church, Chennai, for the first time she feels that Christianity can be dynamic, living faith that can evolve and spread without interference from a human hierarchy.

As a medium that presents information about the wider world, Holy Cow has generated considerable uncertainty and unease in readers. She makes some horrible mistakes in relaying basic acts of modern Indian culture. Her interpretation of the giving of the rakhee and speaking a Shakespearean style of Hindi within weeks of beginning Hindi classes are some imagination at play. The ethnographic notes of the book may be a bit superficial but 
it is much more serious than the quasi-comical title "Holy Cow". Her discussion of the eponymous cow and the traffic rules do hurt Indian sentimentality:

I've always thought it hilarious that Indian people chose the most boring, domesticated, compliant and stupid animal on earth to adore, but already I'm seeing cows in a whole different light. These animals clearly know they rule and like to mess with our heads. ... But for animals powerful enough to stop traffic and holy enough that they will never become steak, cows are treated dreadfully. Scary and sickly, they survive by grazing on garbage that's dumped in plastic notes.( )

Macdonald oversimplified it by talking of it in terms of shallow terms such as syncretism and plurality in India. The title of the book and the first image on the cover seems very funny to a non-Hindu but it is certainly hurting the sentiments of followers of Hinduism in general and Lord Shiva in particular. The occasional smugness and certain off notes leave one with the question how is India projected through her work. And what a person in India feels about the religious and spiritual practices is as important as that of the West. In fact there are some common approaches to the divine in India that cuts creeds and confessions. The book doesn't shed much new information about India but it captures the Indian diversity, the attitude of the people, and a person's spiritual quest, but one feels too much of generalisation for a country as vivid and diverse as India.

Macdonlad sets up a very simple East/West binary that ignores India' history and cultural heritage. Holy Cow has instilled interest in many to have a scholarly study of the religious and cultural traditions of India but one with critical thinking skill can easily understand the ubiquitous orientalis $\mathrm{m}$ in the book. The book should not be taken as a source of authentic description about any religion, faith or culture for it is just a personal account of the impression India gave Sarah. At times, Sarah feels her histrionics as part of Indian faith but unlike other Westerners, Sarah Macdonald is not carried away by it. Sarah says she is reborn as a better person in India, "the land of the profound and the profane; a place where spirituality and sanctimoniousness sit miles apart" (318). The hilarious graphic descriptions about India and Indians, and the comparisons make one baffled as how far is she successful in challenging the stereotyped conventions and assumptions about India. India remains a cataclysmic crowded land of her rebirth and Sidney, the quiet empty lands of her birth. The oriental undercurrent runs even in the closing note when she talks about the shadow cast by India in their lives: "We now both have a new view of our so lucky lives, yet our innocent optimis m about humanity has been sucked from our hearts"(317).

\section{REFERENCES}

[1] Bhabha, HomiK.The Location of Cultures: London: Routledge, 1994.

[2] Blunt, Alison. Travel, Gender and Imperialism: Mary Kingsley and West Africa: New York: Guilford, 1994.

[3] Hulme, Peter, and Tim Youngs, eds. The Cambridge Companion to Travel Literature. United Kingdom: Cambridge UP, 2002.

[4] Macdonald, Sarah. Holy Cow! An Indian Adventure. London: Banton Books, 2002.

[5] Thompson, Carl. Travel Writing. London: Routledge, 2011. 